\title{
Analysis of Results of Test Resistance Isolation Power Transformator Based on Polarization Index Test and Delta Tanngen
}

\author{
Elih Mulyana ${ }^{1}$, Hasbullah $^{2}$, Dzikri Sayefullah ${ }^{3}$ \\ Departemen Pendidikan Teknik Elektro, Fakultas Pendidikan Teknologi dan Kejuruan, \\ Universitas Pendidikan Indonesia, Bandung, Indonesia ${ }^{1}$ \\ Departemen Pendidikan Teknik Elektro, Fakultas Pendidikan Teknologi dan Kejuruan, \\ Universitas Pendidikan Indonesia, Bandung, Indonesia ${ }^{2}$ \\ Departemen Pendidikan Teknik Elektro, Fakultas Pendidikan Teknologi dan Kejuruan, \\ Universitas Pendidikan Indonesia, Bandung, Indonesia ${ }^{3}$ \\ email: elih_mulyana@upi.edu
}

\begin{abstract}
The transformer is the leading equipment in the electric power system that is directly related to the electrical transmission and distribution system. An essential part of a power transformer is its insulation system. Along with age and its operation, the condition of insulation can be damaged, which can lead to failure of the surgery. The purpose of this study was to determine the quality conditions of the power transformer insulation. The method in this research is observation and study of literature, while the research location is PT PLN (Persero) TJBT APP Cirebon. Data were taken in the form of polarization index and delta tangent test results. After the data is collected, the polarization index and delta tangent are calculated and analyzed. Analysis of the polarization index testing using the primary-ground, secondary-ground, tertiary-ground, primary-secondary, secondary-tertiary, and primary-tertiary methods. Whereas tangent delta testing is the relationship between CH, CHL, CL, CT, CHT, and CLT. The results of tests with delta polarization and tangent indexes that the transformer isolation resistance is still good and the transformer is feasible to operate.
\end{abstract}

Keywords: Insulation resistance testing; Polarization index, and Tangent delta

\section{INTRODUCTION}

Power transformer has a very important role in the electricity distribution system, because it is directly related to the transmission system and distribution system. The function of a power transformer converts electrical power from high voltage to low voltage or from low voltage to high voltage. Low-voltage and high-voltage coil construction and body are protected by insulation. Disturbances in the transformer due to the failure of insulation can cause a break in the electrical power of consumers, therefore maintenance and testing of insulation is very necessary to be done routinely and periodically so that the transformer can operate properly in accordance with the maximum age specified by the factory. In the operating system the isolation transformer becomes a very important part in separating the voltage.

In the operating condition the transformer insulation can decrease in strength or penetrating power so that the transformer will experience an operation failure or damage[3]. Damage to the insulation on the transformer can be caused by several factors such as excess voltage, humidity, high operating temperatures or mechanical damage.

To anticipate the failure of the transformer during operation, a number of important tests such as the polarization index and delta tangent tests are carried out. By means of routine testing the isolation of the transformer will be well controlled and 
operation continuity can be maintained well.

\section{METHODS}

The first thing to do in this research is to determine the research objectives, which are as follows to know the test results and calculation of the power transformer insulation resistance based on the polarization index test. Other that that to know the test results and forecast of the power transformer insulation resistance based on the delta tangent test. And to know the quality of the power transformer insulation resistance based on the polarization index test and the tangent delta.

The procedure in research certainly needs to be considered. Systematic steps will provide direction in the work process and can facilitate the process of understanding the desired goals. Figures 2.1 and 2.2 are flow diagrams can be explained more clearly the stages of research as follows:
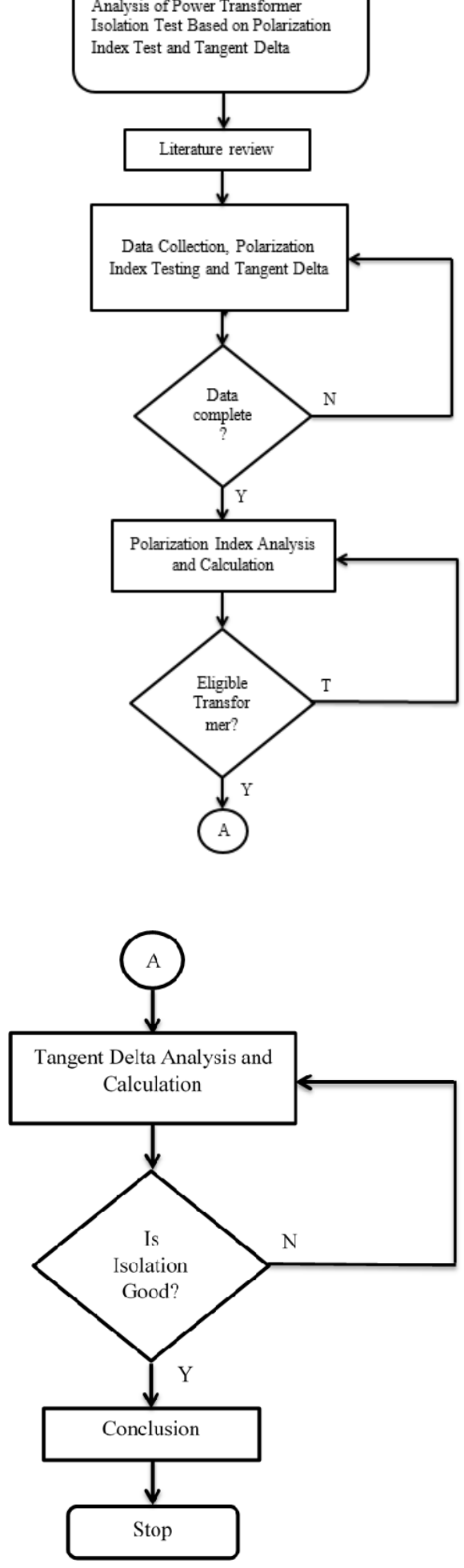

Image 2. 1 Flow Chart of Final Project Research 


\section{RESULT AND DISCUSSION}

The results of polarization index testing

The results of testing the polarization index are to ensure that the equipment is suitable for operation or even for overvoltage tests. The polarization index is the ratio of insulation resistance at minute 10 to minute 1 with a constant voltage.

The polarization index method is used to test one piece of equipment, to find the insulation resistance of the material and focus on its insulation

The results of testing the insulation transformer of a power transformer at transformer four sunyaragi using the polarization index method as follows[7]

Table 3.1 The results of polarization

$$
\text { index testing }
$$
$1,1-1,2$
$1,0-1,1$
Be Questioned
Bad
$>1,0$
Dangerous

The parameter value of the Polarization Index (IP) according to the IEEE 43-2000 standard on Polarization Index and Isolation Resistance.

\section{The results of polarization index calculation}

The results of index polarization in 2016 and 2018 as follows [3]:

$\operatorname{Primary}(\mathrm{P})-\operatorname{Ground}(\mathrm{G}) \quad \mathrm{IP}=\frac{7,59}{5,94}=$ 1,27

Secondary(S)-Ground

$$
\mathrm{IP}=\frac{5,58}{3,47}=
$$
1,6

$\operatorname{Tertiary}(\mathrm{T})-\mathrm{Ground}(\mathrm{G}) \quad \mathrm{IP}=\frac{2,83}{2,77}=$ 1,02

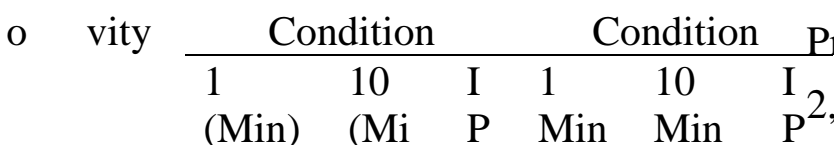

$\begin{array}{ll}\text { Primary(P)-Secondary }(\mathrm{S}) & \mathrm{IP}=\frac{7,02}{3,16}= \\ \text { Primary(P)-Tertiary(T) } & \text { IP }=\frac{6,88}{5,52}= \\ 1,24 & \\ \text { Secondary }(\mathrm{S})-\operatorname{Tertiary}(\mathrm{T}) & \mathrm{IP}=\frac{3,19}{2,1}= \\ \text { 1,52 } & \\ \text { rimary(P)-Ground }(\mathrm{G}) & \mathrm{IP}=\frac{4,48}{3,54}=\end{array}$ n) $\quad \operatorname{Primary}(\mathrm{P})-\operatorname{Tertiary}(\mathrm{T})$

\begin{tabular}{llllll}
\hline 1 & P-G & 5,94 & 7,59 & 3,54 & 4,48 \\
2 & S-G & 3,47 & 5,58 & 1,98 & 4,42 \\
3 & T-G & 2,77 & 2,83 & 1,62 & 4,18 \\
4 & P-S & 3,16 & 7,02 & 3,12 & 4,17 \\
5 & P-T & 5,52 & 6,88 & 4,39 & 6,39 \\
6 & S-T & 2,1 & 3,19 & 1,82 & 2,95 \\
\hline
\end{tabular}

The polarization index test results on minute 1 - minute 10 on primaryground, secondary-ground, tertiaryground, primary-secondary, primarytertiary, and secondary-tertiary increased.

1,26

$\operatorname{Secondary}(\mathrm{S})-\operatorname{Ground}(\mathrm{G}) \quad \mathrm{IP}=\frac{4,42}{1,98}=$ 2,48

Tertiary(T)-Ground(G) $=2,58$

Table 3.2 Standard of polarization index test result

\begin{tabular}{ll}
\hline Test Result & Information \\
\hline$>2$ & Excellent \\
$1,25-2$ & Good
\end{tabular}

$$
\mathrm{IP}=\frac{4,18}{1,62}
$$$$
\mathrm{IP}=\frac{4,17}{3,12}=
$$ 
$\operatorname{Primary}(\mathrm{P})-\operatorname{Tertiary}(\mathrm{T}) \quad \mathrm{IP}=\frac{6,39}{4,39}=$

$\operatorname{Secondary}(\mathrm{S})-\operatorname{Tertiary}(\mathrm{T}) \quad \mathrm{IP}=\frac{2,95}{1,82}=$ 1,62

Table 3.3 The results of polarization index calculation

\begin{tabular}{lllllllll}
\hline No & $\begin{array}{l}\text { Acti } \\
\text { vity }\end{array}$ & \multicolumn{2}{l}{$\begin{array}{l}2016 \\
\text { Condition }\end{array}$} & \multicolumn{4}{l}{$\begin{array}{l}2018 \\
\text { Condition }\end{array}$} & \multirow{2}{*}{$\begin{array}{l}\text { Inforn } \\
\text { on }\end{array}$} \\
\cline { 3 - 8 } & & 1 & 10 & IP & 1 & 10 & IP & \\
& & Min & Min & & Min & Min & & \\
\hline 1 & P-G & 5,94 & 7,59 & 1,27 & 3,54 & 4,48 & 1,26 & Good
\end{tabular}

\begin{tabular}{lllllllll}
\hline 2 & S-G & 3,47 & 5,58 & 1,6 & 1,98 & 4,42 & 2,48 & Excel \\
\hline 3 & T-G & 2,77 & 2,83 & 1,02 & 1,62 & 4,18 & 2,58 & Excel \\
\hline 4 & P-S & 3,16 & 7,02 & 2,22 & 3,12 & 4,17 & 1,50 & Good \\
\hline 5 & P-T & 5,52 & 6,88 & 1,24 & 4,39 & 6,39 & 1,45 & Good \\
\hline 6 & S-T & 2,1 & 3,19 & 1,52 & 1,82 & 2,95 & 1,62 & Good \\
\hline
\end{tabular}

The results of the calculation of the polarization index on measurements of primary-ground, secondary-ground, tertiary-ground, primary-secondary, primary-tertiary, secondary-tertiary are in proper limits by IEEE 43-2000 standards. The transformer is suitable for operation.

\section{The result of delta tangent testing}

Tangent delta aims to determine the condition of isolation characteristics that have deteriorated or not. The results of testing the transformer insulation resistance of power transformer 4 in sunyaragi using the delta tangent method as follows :

Table 3.4 The result of delta tangent testing

\begin{tabular}{llllllll}
\hline $\begin{array}{l}\text { Measureme } \\
\text { nts }\end{array}$ & $\begin{array}{l}\text { Test } \\
(\mathrm{kV})\end{array}$ & $\begin{array}{c}\mathrm{I} \\
(\mathrm{mA})\end{array}$ & $\begin{array}{l}\mathrm{P} \\
\text { (Watt) }\end{array}$ & $\begin{array}{l}\text { Pf } \\
(\%)\end{array}$ & $\begin{array}{l}\text { Corr } \\
\text { Factor }\end{array}$ & Cap (Pf) & Inf \\
\hline CH+CHL & 10 & 30,843 & 0,7186 & & 0,630 & 9823,80 & \\
\hline CH & 10 & 9,579 & 0,3228 & 0,630 & 3052,98 & \\
\hline CHL (UST) & 10 & 21,282 & 0,4021 & 0,630 & 6786,66 & \\
\hline CHL & 10 & 21,264 & 0,396 & & 0,630 & 6770,82 & \\
\hline CL+CLT & 10 & 47,581 & 1,1522 & 0,630 & 15146,07 & \\
\hline CL & 10 & 4,121 & 0,2889 & 0,630 & 1312,45 & \\
\hline CLT (UST) & 10 & 43,484 & 0,8646 & 0,630 & 13859,38 \\
\hline CLT & 10 & 43,460 & 0,863 & 0,630 & 13833,61 \\
\hline CT+CHT & 10 & 16,711 & 0,2592 & 0,630 & 10636,61 \\
\hline CT & 10 & 16,333 & 0,2507 & 0,630 & 10431,15 \\
\hline CHT (UST) & 10 & 0,326 & 0,0080 & 0,630 & 207,87 \\
\hline CHT & 10 & 0,376 & 0,008 & 0,630 & 205,75 \\
\hline
\end{tabular}

Delta tangent test results on the method $\mathrm{CH}+\mathrm{CHL}, \mathrm{CH}, \mathrm{CHL}$ (UST), CHL, CL+CLT, CL, CLT (UST), CLT, $\mathrm{CT}+\mathrm{CHT}, \mathrm{CT}, \mathrm{CHT}$ (UST), CHT to get the results $\mathrm{Pf} \%$.

Table 3.5 Delta tangent testing standards

\begin{tabular}{ll}
\hline Test Results & Information \\
\hline$<0,5 \%$ & Good \\
$0,5 \%-0,7 \%$ & Deteriorating \\
$>1,0 \%$ & Bad \\
\hline
\end{tabular}

Based on ANSI C 57.12.90 interpretation of delta tangent test results.

\section{The result of delta tangent calculation}

Delta tangent calculation results to find out the results of $\mathrm{Pf} \%$ to determine whether the insulation conditions are good or deteriorating[7].

Calculation of $\mathrm{CH}+\mathrm{CHL}$ delta tangent test results :

$$
\begin{array}{ll}
\mathrm{P} & : 0,7186 \mathrm{Watt} \\
\mathrm{V} & : 10.000 \text { Volt } \\
\mathrm{C} & : 9823,80 \mathrm{pF}=9823,80 \times 10^{-12} \\
\mathrm{~F} & \\
\omega & : 2 \times 3,14 \times 50
\end{array}
$$

Result :

$\operatorname{Tan} \delta=$

$$
\begin{aligned}
& \frac{0,7186}{10.000^{2} \times 2 \times 3,14 \times 50 \times 9823,80 \times 10^{-12}} \times 100 \% \\
& =0,23 \%
\end{aligned}
$$

One of delta tangent calculation from several methods that get results $<5 \%$ or in a state of good isolation except the CL method.

Calculation of CL delta tangent test results :

P : : 0,2889 Watt 


$$
\begin{array}{ll}
\mathrm{V} & : 10.000 \text { Volt } \\
\mathrm{C} & : 1312,45 \mathrm{pF}=1312,45 \times 10^{-12} \\
\mathrm{~F} & \\
\omega & : 2 \times 3,14 \times 50
\end{array}
$$

Result :

$\operatorname{Tan} \delta=$

$$
\begin{aligned}
& \frac{0,2889}{10.000^{2} \times 2 \times 3,14 \times 50 \times 1312,45 \times 10^{-12}} \times 100 \% \\
& =0,70 \%
\end{aligned}
$$

In the CL method the calculation results get $0.5-0.7 \%$ and the insulation was deteriorating

Table 3.6 The result of delta tangent calculation

\begin{tabular}{lllllll}
\hline $\begin{array}{l}\text { Measureme } \\
\text { nts }\end{array}$ & $\begin{array}{l}\text { Test } \\
(\mathrm{kV})\end{array}$ & $\begin{array}{c}\mathrm{I} \\
(\mathrm{mA})\end{array}$ & $\begin{array}{l}\text { P } \\
(\text { Watt })\end{array}$ & $\begin{array}{l}\text { Pf } \\
(\%)\end{array}$ & $\begin{array}{l}\text { Corr } \\
\text { Factor }\end{array}$ & Cap (Pf) \\
\hline CH+CHL & 10 & 30,843 & 0,7186 & 0,23 & 0,630 & 9823,80 \\
\hline CH & 10 & 9,579 & 0,3228 & 0,34 & 0,630 & 3052,98 \\
\hline CHL (UST) & 10 & 21,282 & 0,4021 & 0,19 & 0,630 & 6786,66 \\
\hline CHL & 10 & 21,264 & 0,396 & 0,19 & 0,630 & 6770,82 \\
\hline CL+CLT & 10 & 47,581 & 1,1522 & 0,24 & 0,630 & 15146,07 \\
\hline CL & 10 & 4,121 & 0,2889 & 0,70 & 0,630 & 1312,45 \\
& & & & & & \\
\hline CLT (UST) & 10 & 43,484 & 0,8646 & 0,20 & 0,630 & 13859,38 \\
\hline CLT & 10 & 43,460 & 0,863 & 0,20 & 0,630 & 13833,61 \\
\hline CT+CHT & 10 & 16,711 & 0,2592 & 0,08 & 0,630 & 10636,61 \\
\hline CT & 10 & 16,333 & 0,2507 & 0,08 & 0,630 & 10431,15 \\
\hline CHT (UST) & 10 & 0,326 & 0,0080 & 0,12 & 0,630 & 207,87 \\
\hline CHT & 10 & 0,376 & 0,008 & 0,12 & 0,630 & 205,75 \\
\hline
\end{tabular}

The test results and average delta tangent calculations are in good condition under the desired standard $<0.5 \%$, but some tests exceed the reasonable limit of Capacitance low (CL), but the transformer is still feasible to operate.

\section{The quality of the power transformer insulation resistance is based on the polarization index test and delta tangent}

The quality of the power transformer insulation resistance based on the transformer polarization index test at GI Sunyaragi from 2016-2018 shows that the transformer is still in good condition because the test results are above 1.25-2 so that the transformer is always safe to operate.

The quality of the calculation results in Table 4.6 can be concluded that the condition of the transformer winding insulation resistance in GI Sunyaragi is still feasible to operate but is still under supervision. The average delta tangent test results are still useful in the desired standard $<0.5 \%$, but some tests exceed the reasonable limit that is Capacitance low (CL). In CL mode, there is a deterioration or increase that exceeds the test standard in GI Sunyaragi by $0.5 \%-0.7 \%$, but the transformer is still feasible to operate. This can be caused by contamination or leakage of current in the transformer winding insulation, so that further investigation is needed to avoid worsening in other tests.

\section{CONCLUSION}

The results of the testing and calculation of the polarization index in the transformer 4 Sunyaragi substation indicate the condition of the transformer is feasible to operate. Aside from that The test results and average delta tangent calculations are in good condition, but some counts exceed the reasonable limit of CL mode.

The quality of the power transformer insulation resistance based on the polarization index test is still in good condition because the test results are between 1.25-2, so that the transformer insulation resistance is still safe to operate and the average delta tangent test results are still well within the desired standard of $0.5 \%$, but there are some tests that exceed the reasonable limit, it's CL. But the transformer is still feasible to operate. 


\section{REFERENCES}

Andi M, (2018). Pengujian tahanan isolasi dan rasio trafo PS T15 PT Indonesia Power UP MRICA . Jurnal energi dan kelistrikan vol. 10 no. 1 .

Hadha A. (2010). Pemeliharaan Transformator Daya Pada Gardu Induk $150 \mathrm{kV}$ Srondol PT. PLN (Persero) P3B Jawa Bali Region Jawa Tengah dan DIY UPT Semarang

Marsudi, J. (2006). Operasi Sistem Tenaga Listrik. (edisi pertama). Yogyakarta: Penerbit Graha Ilmu.

PT PLN (Persero). (2014). Buku panduan pedoman pemeliharaan transformator tenaga . Jakarta.

Rakhmad F. (2014). Analisis pengujian tahanan isolasi trafo daya 10MVA 70/20KV pada gardu induk talang PT PLN (Persero) Palembang. (Skripsi). Jurusan Teknik Elektro Program Studi Seknik Listrik, Politeknik Negeri Sriwijaya.

Standard IEEE 43-2000, IEEE Recommended Practice for Testing Insulation Resistance of Rotating Machinery

Zuhal. (1991). Dasar Tenaga Listrik (edisi sepuluh) Bandung: Penerbit ITB. 